\title{
Reproductive success in Calanus helgolandicus as a function of diet and egg cannibalism
}

\author{
Hyung-Ku Kang, Serge André Poulet* \\ Station Biologique de Roscoff, CNRS et Université Paris VI, 29682 Roscoff, France
}

\begin{abstract}
Calanus helgolandicus females were incubated for 6 to $25 \mathrm{~d}$ in single and mixed diets of the diatom Coscinodiscus curvatulus and the dinoflagellate Gymnodinium sanguineum using 2 incubation protocols, and fecundity, hatching success, egg cannibalism and faecal pellet production were measured. Both fecundity and hatching success were significantly reduced by single or mixed diets containing high concentrations of diatoms. The deleterious effect of the diatom was diminished when females were fed diets containing low diatom concentration and also when egg cannibalism represented $\mathrm{ca}>20 \%$ of the total daily egg production. Egg cannibalism was higher with the wheel-incubation method than with the vial-incubation method. The results suggest that diatom inhibition of copepod reproduction can be reduced in various ways, including decreasing the diatom concentration, switching from diatom to dinoflagellate diets, increasing the diversity of food items and also by egg cannibalism (eggs are of high nutrient value).
\end{abstract}

KEY WORDS: Copepod · Calanus helgolandicus $\cdot$ Reproduction $\cdot$ Food

\section{INTRODUCTION}

Accumulating laboratory evidence shows that several species of diatoms, at high concentrations $\left(\geq 10^{3}\right.$ cells $\left.\mathrm{ml}^{-1}\right)$, are deleterious for copepod reproduction (Ban et al. 1997). Ingestion of diatoms by adult female copepods is followed by low egg production and low hatching success, including abnormal egg and nauplii development (Poulet et al. 1994, 1995, Uye 1996, Lee et al. 1999). The inhibition is reversible when the diatom diet is replaced by a dinoflagellate diet (Laabir et al. 1995b, Uye 1996). The higher the density of diatoms and the longer they are ingested, the lower the hatching success and vice versa (Chaudron et al. 1996). Recently, 3 aldehydes, purified from diatom extracts, have been identified and bioassays have shown that they cause low egg viability (Ianora et al. 1999b, Miralto et al. 1999). In addition to diatom inhibition, other evidence has shown some diatoms species to be insufficiently nutritious to enable successful copepod repro-

\footnotetext{
*Corresponding author. E-mail: poulet@sb-roscoff.fr
}

duction (Støttrup \& Jensen 1990, Jónasdóttir 1994, Jónasdóttir \& Kiørboe 1996). Moreover, some essential fatty acids may be lacking from diatom diets (Jónasdóttir \& Kiørboe 1996, Pond et al. 1996). This well-documented evidence of the deleterious effects and nutritional insufficiency of diatoms in laboratory conditions raises questions as to the effect of diatoms on copepods in the field.

In nature, copepod diets are diverse and include various phytoplankton and microzooplankton taxa, bacteria and metazoans (see Mauchline 1998 for review) and probably influence copepod reproduction and consequently recruitment of populations. Despite dietary diversity, it is still unclear what influence food selectivity has on reproduction and how the deleterious effect of diatoms can be mediated by mixed diets. Lee et al. (1999) examined the link between feeding selectivity and reproductive responses in the copepod Pseudocalanus newmani and demonstrated the positive influence of mixed diets on its fecundity and hatching success. Mixed diets can provide essential compounds such as vitamins, amino acids and fatty acids that may be lacking in single diets (Harrison 1990).

Calanus spp. are known to eat their own eggs 
(Conover 1960, Turner 1984, Laabir et al. 1995a) and thus in nature, a fraction of the eggs they spawn are lost to cannibalism (Kiørboe et al. 1988, Liang et al. 1994, Peterson \& Kimmerer 1994). Laabir et al. (1995a) reported that $C$. helgolandicus ingested their eggs and that cannibalism increased both with increasing female density in the incubators and with increasing level of starvation, and decreased again after addition of food. Therefore, eggs produced by females constitute an additional type of food, that may modify the nutritional value of single or mixed algal diets. This effect of egg cannibalism has never been evaluated during fecundity/hatching measurements.

The aim of this study was thus to evaluate variations in the reproductive response of Calanus helgolandicus, to 'modifications' of normal diets (diatom and dinoflagellate in single and mixed diets) by the copepod eggs produced during the incubations. The experiments were performed at different food concentrations and used 2 methods of incubation to determine the effect of various proportions of diatoms among other food components on the selective feeding of copepods.

\section{MATERIALS AND METHODS}

Copepod sampling. Calanus helgolandicus females were collected from 21 July to 10 October 1998 by towing $500 \mu \mathrm{m}$ mesh-net obliquely from $20 \mathrm{~m}$ to the surface offshore from Roscoff, France (Western English Channel). They were kept in an insulated box until arrival in the laboratory (within 1 to $2 \mathrm{~h}$ after collection). Adult females were sorted and placed in incubators filled with ambient seawater at $13.4 \pm 0.4^{\circ} \mathrm{C}$. After $24 \mathrm{~h}$ acclimation, fecundity and egg viability were estimated; these served to represent the initial reproductive condition of females on the various sampling dates and were used as control values for each experiment.

Phytoplankton culture. Two similar-sized phytoplankton species, the diatom Coscinodiscus curvatulus and the dinoflagellate Gymnodinium sanguineum, were used in the feeding and fecundity experiments
(Table 1). They were cultured in $\mathrm{K}$ medium (Keller et al. 1987) with the addition of silicate to the diatoms, at $17^{\circ} \mathrm{C}$ under a $14 \mathrm{~h}$ light:10 h dark cycle at light intensity of $\sim 117 \mu \mathrm{E} \mathrm{m} \mathrm{m}^{-2} \mathrm{~s}^{-1}$ and were fed to the copepods in their exponential phase of growth (Uye 1996, Ianora et al. 1999a) (although Jónasdóttir [1994] made distinctions in food quality between the early, mid- and lateexponential phases of growth, this was not done in the present study).

Feeding experiments. Five types of food treatments comprising a diatom-dinoflagellate combination (dia, din) were fed to the females in the following ratios: 1:0 (Sdia), 4:1 (HdiaLdin), 1:1 (Sratio), 1:4 (LdiaHdin), 0:1 (Sdin) (Table 2); total cell volume was constant at $2.5 \times$ $10^{7} \mu^{3} \mathrm{ml}^{-1}$. Six $310 \mathrm{ml}$ jars each containing 3 females, and 2 control jars without females were enriched with 1 of the 5 food treatments and placed on a gently rotating wheel (5 to $6 \mathrm{rpm}$ ) at $13.4 \pm 0.4^{\circ} \mathrm{C}$ under dim light and a natural light cycle (hereafter 'wheel' incubation method). The females were acclimated to each type of diet for $24 \mathrm{~h}$. Feeding experiments were run for $6 \mathrm{~d}$ with the mixed diets (HdiaLdin, Sratio and LdiaHdin) and $7 \mathrm{~d}$ with the single diets (Sdia and Sdin). Phytoplankton samples $(3 \mathrm{ml})$ were taken from each experimental and control jar at the beginning and end of each day in each food treatment, fixed with Lugol's solution and then counted on a Sedgewick-Rafter

Table 2. Cell concentration of 5 diet treatments (ratio diatoms:dinoflagellates, based on cell volume) using diatom Coscinodiscus curvatulus and dinoflagellate Gymnodinium sanguineum in mixed and single diets fed to Calanus helgolandicus

\begin{tabular}{|lccc|}
\hline \multirow{2}{*}{$\begin{array}{l}\text { Diet } \\
\text { treatment }\end{array}$} & Acronym & \multicolumn{2}{c|}{$\begin{array}{c}\text { Cell concentration (cells ml } \\
\text { C. }\end{array}$} \\
\hline $1: 0$ & & C. curvatulus & G. sanguineum \\
$4: 1$ & Sdia & $1.6 \times 10^{3}$ & 0 \\
$1: 1$ & HdiaLdin & $1.3 \times 10^{3}$ & $2.1 \times 10^{2}$ \\
$1: 4$ & Sratio & $8 \times 10^{2}$ & $5.3 \times 10^{2}$ \\
$0: 1$ & LdiaHdin & $3.2 \times 10^{2}$ & $8.5 \times 10^{2}$ \\
& Sdin & 0 & $1.1 \times 10^{3}$ \\
\hline
\end{tabular}

Table 1. Characteristics of phytoplankton species used as diets in feeding and fecundity experiments with Calanus helgolandicus. Cell volumes converted into cell-carbon contents according to equation of Strathmann (1967). -: no data

\begin{tabular}{|c|c|c|c|c|c|c|c|}
\hline \multirow[t]{2}{*}{ Species } & \multirow[t]{2}{*}{ Clone } & \multicolumn{3}{|c|}{ Size $(\mu \mathrm{m})$} & \multirow{2}{*}{$\begin{array}{l}\text { Volume } \\
\left(\mu \mathrm{m}^{3}\right)\end{array}$} & \multirow{2}{*}{$\begin{array}{l}\text { Carbon } \\
\text { (pg C) }\end{array}$} & \multirow[t]{2}{*}{ Location } \\
\hline & & Length & Width & Thickness & & & \\
\hline $\begin{array}{l}\text { Coscinodiscus } \\
\text { curvatulus }\end{array}$ & RCC77 & 19.1 & 32.2 & - & 15554 & 569 & $\begin{array}{c}\text { North Atlantic } \\
\text { (off Roscoff, France) }\end{array}$ \\
\hline $\begin{array}{l}\text { Gymnodinium } \\
\text { sanguineum }\end{array}$ & RCC89 & 50.1 & 34.1 & 26.4 & 23453 & 2113 & $\begin{array}{l}\text { North Atlantic } \\
\text { (off Florida, USA) }\end{array}$ \\
\hline
\end{tabular}


chamber. Female ingestion rates were calculated according to Frost's (1972) equation. In addition to ingestion rate, egg cannibalism, fecundity and egg viability were monitored daily. Egg cannibalism was expressed as the percentage of crumpled and empty egg membranes that remained on the bottom of the jar or were counted in the faecal pellets relative to the total number of eggs produced daily.

Fecundity measurements. Fecundity and egg viability were measured parallel to female ingestion rate. The food treatments were the same as in the feeding experiments (see Table 2). Thirty females were acclimated to the experimental conditions for $24 \mathrm{~h}$, and those that laid eggs ( $22 \leq \mathrm{n} \geq 30$ females) were each transferred to an individual vial ( $300 \mathrm{ml} \mathrm{vol})$ containing $100 \mathrm{ml}$ of one of the diets (Table 2) and were maintained at $13.4 \pm 0.4^{\circ} \mathrm{C}$ under dim light and a natural light cycle. Algae were kept in suspension manually 5 to 6 times a day. The females were transferred daily to new containers with fresh food. The experiments were run for $6 \mathrm{~d}$ with the mixed diets (HdiaLdin, Sratio and LdiaHdin) and $9 \mathrm{~d}$ with the single diets (Sdia and Sdin). Fecundity, egg viability and egg cannibalism were recorded each day, and the number of viable eggs (NVE) was calculated as a product of fecundity and hatching rate. Some females spawned unfertilised eggs (e.g. fragile eggs lacking membrane) during the incubation periods, and these were excluded from the fecundity estimations. Egg viability was determined by incubating each batch of $n \geq 10$ eggs in a chamber containing $2 \mathrm{ml}$ filtered seawater $(0.22 \mu \mathrm{m})$ for a period of $<72 \mathrm{~h}$. Female survival was $\sim 100 \%$ in all dietary treatments.

Diet-shift experiments. To examine the possible deleterious effect of the diatom Coscinodiscus curvatulus without any egg-cannibalism artefact and to determine how reproductive success may change as a function of shift in diet, a high concentration $\left(1 \times 10^{4} \mathrm{cells} \mathrm{m}^{-1}\right)$ of the diatom was first provided to the females over a period of $15 \mathrm{~d}$; the diet was then replaced by the dinoflagellate Gymnodinium sanguineum $\left(4 \times 10^{2}\right.$ cells ml- $\left.{ }^{-1}\right)$ for 10 further days (Days 16 to 25). Each of the 30 females was individually maintained in a vial $(300 \mathrm{ml}$ vol $)$ under the same conditions as the fecundity measurements with the mixed and single diets (hereafter 'vial' incubation method). Fecundity, egg viability, faecal pellet production and egg cannibalism were monitored daily.

Data analysis. Mean and standard deviation of percentage egg viability and egg cannibalism were calculated from arcsine-transformed values. The percentage data were arcsine-transformed (Zar 1984) prior to statistical analyses to normalise the variance, and parametric tests were then applied (e.g. Student's $t$-test or 1-way ANOVA test, followed by a Tukey's post hoc comparison). The ingestion rates, fecundity, faecal pellet production and NVE data were analyzed by non-parametric tests (e.g. Mann-Whitney $U$-test or Kruskal-Wallis ANOVA test, followed by a MannWhitney $U$-test post hoc comparison). All statistical analyses used the STATISTICA programme for Windows (StatSoft Inc.).

\section{RESULTS}

\section{Feeding selectivity}

Non-selective feeding of Calanus helgolandicus females was observed for 5 diet treatments (Table 2) for 6 or $7 \mathrm{~d}$, confirming that these females ingested both diets at different rates, depending on food concentration (Fig. 1). In the mixed diet treatments (HdiaLdin, Sratio and LdiaHdin; Fig. 1A,B,C), mean ingestion rates were always significantly higher for diets with high cell concentrations than for those with low cell concentrations (Table 3). With the Sratio diet, ingestion of the diatom Coscinodiscus curvatulus was higher than of the dinoflagellate Gymnodinium sanguineum, since the relative cell concentration of the diatom was higher than that of the dinoflagellate (cellvolume difference). With HdiaLdin, ingestion of diatoms fluctuated, while ingestion of dinoflagellates was fairly stable. With both the Sratio and LdiaHdin diets, ingestion rates dropped temporarily on Day 5 (Fig. 1B,C); mean ingestion rates of the diatom and dinoflagellate were the same in both treatments (Mann-Whitney $U$-test, $\mathrm{p}>0.05$ ). For the single-diet treatments (Sdia and Sdin; Fig. 1D), the mean ingestion rate was significantly higher with Sdia than with Sdin (Mann-Whitney $U$-test, $\mathrm{p}<0.01$ ). A comparison of the mean ingestion rates for $6 \mathrm{~d}$ between mixed- and single-diet treatments revealed these rates to be proportional to the concentration of the diatom or dinoflagellate concentrations in the respective diets: ingestion of the diatom in the HdiaLdin and Sdia diets was significantly higher than in the Sratio diet, and was lowest in the LdiaHdin diet (Kruskal-Wallis ANOVA test, $H[\mathrm{df}=3, \mathrm{n}=141]=78.92, \mathrm{p}<0.0001)$. Ingestion of the dinoflagellate from the Sdin diet was significantly higher than from the LdiaHdin and Sratio diets, and lowest in the HdiaLdin diet (Kruskal-Wallis ANOVA test, $H[\mathrm{df}=3, \mathrm{n}=142]=37.64, \mathrm{p}<0.0001)$.

\section{Fecundity and egg viability in mixed- and single-diet experiments}

The effects of mixed and single diets on fecundity in the vial experiments were compared. Fecundity of Calanus helgolandicus females varied with diet 

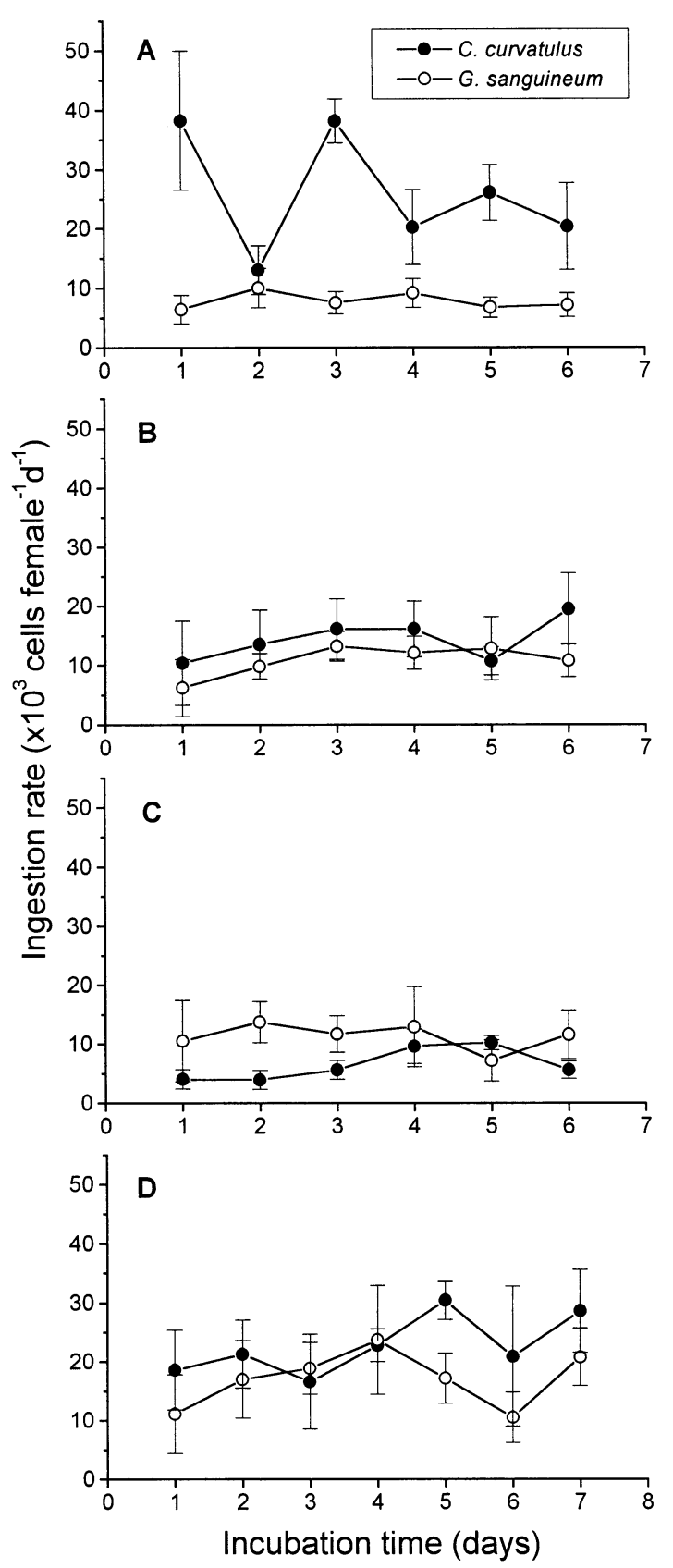

Fig. 1. Calanus helgolandicus. Comparison between ingestion rates of females fed mixed $(6 \mathrm{~d} ; \mathrm{A}, \mathrm{B}, \mathrm{C})$ and single $(7 \mathrm{~d} ; \mathrm{D})$ diets. Diatom Coscinodiscus curvatulus and dinoflagellate Gymnodinium sanguineum were mixed in ratios 4:1 (A, HdiaLdin), 1:1 (B, Sratio), 1:4 (C, LdiaHdin), and 1:0 (D, Sdia) or 0:1 (D, Sdin), based on cell concentrations (see Table 2), equivalent to a constant cell volume equal to $2.5 \times 10^{7} \mu^{3}$ $\mathrm{ml}^{-1}$. Data are means $\pm \mathrm{SD}$ for $\mathrm{n}=6$ (number of jars)

(Fig. 2). Initial mean in situ fecundity was $9.2 \pm 4.0$ eggs female ${ }^{-1} d^{-1}(n=25)$ with mixed-diet treatments, and there was no significant difference between sampling dates (21 July, 3 and 17 August; Kruskal-Wallis ANOVA test, $H[\mathrm{df}=2, \mathrm{n}=25]=3.35, \mathrm{p}>0.05$ ), indi- cating a similar reproductive condition among all females sampled. Initial fecundity in the mixed-diet treatments (HdiaLdin, Sratio and LdiaHdin) increased significantly after the 1st day (Day 2; Fig. 2) (KruskalWallis ANOVA test, $H$ [df $=3, \mathrm{n}=106]=40.81, \mathrm{p}<$ $0.0001)$; it then continued to increase gradually and significantly with both the HdiaLdin and the LdiaHdin diets (Table 4). In the single-diet treatments (Sdia and Sdin), initial in situ fecundity was close to zero, and mean fecundity increased for $9 \mathrm{~d}$ as in the Sdia and Sdin treatments (Table 4). A comparison of the means for $6 \mathrm{~d}$ (Days 2 to 7 ; Fig. 2) between diet treatments revealed that mixed diets resulted in a better fecundity than single diets (Kruskal-Wallis ANOVA test, $H$ [df = $4, \mathrm{n}=796]=130.45, \mathrm{p}<0.0001)$.

Mean initial in situ egg viability was $83.2 \pm 2.6 \%$ (n $=70$ ) in mixed-diet treatments, and did not differ significantly between sampling dates (Kruskal-Wallis ANOVA test, $\left.F=0.49, \mathrm{df}_{1}=2, \mathrm{df}_{2}=69, \mathrm{p}>0.05\right)$. During the incubation periods, egg viability fluctuated slightly with the HdiaLdin and LdiaHdin diets, gradually decreased with the Sratio diet (Fig. 2), and remained significantly high with the LdiaHdin diet (Table 4). In single-diet treatments, egg viability decreased until the 3rd or 4th day, and then gradually increased (Fig. 2), and was significantly higher with the Sdin diet (Table 4). A comparison of egg viability between mixed- and single-diet treatments over $6 \mathrm{~d}$ showed that mean egg viability with both the Sdin and LdiaHdin diets was higher than with the Sdia diet (ANOVA test, $F=63.64, \mathrm{df}_{1}=4, \mathrm{df}_{2}=661, \mathrm{p}<0.0001$ ). These results indicate that egg viability with either mixed or single diets was proportional to the concentration of the dinoflagellate Gymnodinium sanguineum in the diet; the higher the dinoflagellate concentration, the better the copepod egg viability.

The number of viable eggs (NVE) varied as a function of time and dietary treatment. The overall trends for NVE were similar to those for fecundity variation (Fig. 2), showing better rates with LdiaHdin for the mixed diets and with Sdin for the single diets (Table 4). A comparison of the mean NVE over $6 \mathrm{~d}$ showed that the recruitment rates for copepods fed mixed diets were higher than for those fed single diets (KruskalWallis ANOVA, $H[\mathrm{df}=4, \mathrm{n}=796]=174.87$, $\mathrm{p}<0.001$ ), indicating improvement in recruitment of Stage N1 nauplii by mixed diets.

\section{Fecundity and egg viability related to cannibalism}

For females incubated individually in vials and fed either mixed or single diets, egg cannibalism was negligible (below $\sim 3 \%$ of total daily fecundity), i.e. it represented a negligible artefact in our fecundity and 
Table 3. Calanus helgolandicus. Ingestion rate (cells female $\mathrm{e}^{-1} \mathrm{~d}^{-1}$ ) of females fed the mixed and single diets. Mann-Whitney $U$-test revealed significant differences in ingestion rate between Coscinodiscus curvatulus and Gymnodinium sanguineum for mixed-diet treatments. Data are means of results shown in Fig. 1. -: no data

\begin{tabular}{|lccccc|}
\hline Diet treatment & \multicolumn{2}{c}{ C. curvatulus } & \multicolumn{2}{c}{ G. sanguineum } & Significance \\
& Mean \pm SD & (n) & Mean \pm SD & (n) \\
\hline Mixed diets & & & & & \\
HdiaLdin & $26342 \pm 11387$ & $(35)$ & $7778 \pm 2555$ & $(36)$ & $\mathrm{p}<0.0001$ \\
Sratio & $14473 \pm 6008$ & $(35)$ & $10959 \pm 4016$ & $(35)$ & $\mathrm{p}<0.01$ \\
LdiaHdin & $6487 \pm 3048$ & $(36)$ & $11391 \pm 5005$ & $(35)$ & $\mathrm{p}<0.0001$ \\
Single diets & $22774 \pm 7985$ & $(41)$ & & $(-)$ & \\
Sdia & - & $(-)$ & $17026 \pm 7168$ & $(42)$ \\
Sdin & & & & & \\
\hline
\end{tabular}

Table 4. Calanus helgolandicus. Fecundity, egg viability and number of viable eggs (NVE) of females fed mixed (6 d) and single (9 d) diets with Coscinodiscus curvatulus and Gymnodinium sanguineum. ${ }^{\mathrm{a}, \mathrm{b}, \mathrm{c}}$ Significant differences between diets. Data are means of results in Fig. 2

\begin{tabular}{|c|c|c|c|c|c|c|}
\hline \multirow[t]{2}{*}{ Diet treatment } & \multicolumn{2}{|c|}{ Fecundity (eggs female ${ }^{-1} d^{-1}$ ) } & \multicolumn{2}{|c|}{ Egg viability (\%) } & \multicolumn{2}{|c|}{ NVE (viable eggs female ${ }^{-1} \mathrm{~d}^{-1}$ ) } \\
\hline & Mean \pm SD & (n) & Mean \pm SD & (n) & Mean \pm SD & \\
\hline \multicolumn{7}{|l|}{ Mixed diets } \\
\hline HdiaLdin & $38.4 \pm 15.5$ & $(167)$ & $75.5 \pm 1.7$ & $(142)$ & $29.0 \pm 12.6$ & $(167)$ \\
\hline Sratio & $34.0 \pm 13.3$ & $(128)$ & $76.6 \pm 2.3$ & (139) & $25.9 \pm 10.0$ & $(128)$ \\
\hline LdiaHdin & $41.9 \pm 15.7$ & $(175)$ & $84.6 \pm 0.9$ & $(141)$ & $35.2 \pm 12.9$ & $(175)$ \\
\hline Significance & \multicolumn{2}{|c|}{$\begin{array}{l}\text { LdiaHdin }^{\mathrm{a}} \text { HdiaLdin }^{\mathrm{a}}>\text { Sratio }^{\mathrm{b}} \\
\text { Kruskal-Wallis ANOVA test } \\
H(\mathrm{df}=2, \mathrm{n}=470)=22.39 \\
\mathrm{p}<0.0001\end{array}$} & \multicolumn{2}{|c|}{$\begin{array}{l}\text { LdiaHdin }^{\mathrm{a}}>\text { Sratio }^{\mathrm{b}} \text { HdiaLdin }^{\mathrm{b}} \\
\text { ANOVA test } \\
F=33.485 ; \mathrm{df}_{1}=2, \mathrm{df}_{2}=419 \\
\mathrm{p}<0.0001\end{array}$} & \multicolumn{2}{|c|}{$\begin{array}{l}\text { LdiaHdin }^{\mathrm{a}}>\text { HdiaLdin }^{\mathrm{b}}>\text { Sratio }^{\mathrm{c}} \\
\text { Kruskal-Wallis ANOVA test } \\
H(\mathrm{df}=2, \mathrm{n}=470)=46.58 \\
\mathrm{p}<0.0001\end{array}$} \\
\hline \multicolumn{7}{|l|}{ Single diets } \\
\hline Sdia & $30.1 \pm 12.7$ & $(242)$ & $70.6 \pm 2.0$ & $(203)$ & $21.4 \pm 9.9$ & $(242)$ \\
\hline Sdin & $29.6 \pm 18.2$ & $(252)$ & $86.0 \pm 1.7$ & $(184)$ & $25.1 \pm 15.4$ & $(252)$ \\
\hline Significance & \multicolumn{2}{|c|}{$\begin{array}{l}\text { Mann-Whitney } U \text {-test } \\
\mathrm{p}>0.05 \mathrm{~ns}\end{array}$} & \multicolumn{2}{|c|}{$\begin{array}{l}\text { Student's } t \text {-test } \\
\mathrm{p}<0.0001\end{array}$} & \multicolumn{2}{|c|}{$\begin{array}{l}\text { Mann-Whitney } U \text {-test } \\
\mathrm{p}<0.01\end{array}$} \\
\hline
\end{tabular}

egg-viability measurements. In contrast, high egg cannibalism occurred in both mixed and single diets during the classic feeding experiments, using the rotating wheel. In mixed diets, daily egg cannibalism (Fig. 3) constituted $\sim 30$ to $55 \%$ of total daily fecundity; in single diets cannibalism increased to $>25 \%$ after the 2 nd day (Day 3; Fig. 3). Fig. 4 compares mean fecundity, egg viability and egg cannibalism between the 'wheel' and the 'vial' methods in all diet combinations. There were no significant differences in fecundity between the 2 methods, except for the Sratio and Sdin diets, which for fecundity was higher with the vial method (Fig. 4). Egg viability was significantly higher with the wheel method than with the vial method in all diet treatments except Sdin (Fig. 4). Mean egg cannibalism with the wheel method ranged from 21.4 to $49.2 \%$, and was always significantly lower with the vial method (0.1 to $1.6 \%$ ) (Fig. 4 ).

A comparison of mean fecundity, egg viability and egg cannibalism (pooled data for $6 \mathrm{~d}$ in mixed and $7 \mathrm{~d}$ in single diets; Fig. 5), regardless of diet, revealed egg viability (95.3 $\pm 4.4 \%, \mathrm{n}=494)$ and egg cannibalism $(39.6 \pm 3.8 \%, \mathrm{n}=192)$ in the wheel incubations to be significantly higher than in the vial incubations (egg viability: $78.0 \pm 2.4 \%, \mathrm{n}=714$; egg cannibalism: $0.4 \pm$ $1.2 \%, \mathrm{n}=852$ ). However, mean fecundity did not differ significantly between the 2 incubation methods. These results indicated that egg cannibalism improved egg viability, while fecundity was unaffected.

\section{Changes in fecundity and egg viability as a function of diet}

High concentrations of the diatom Coscinodiscus curvatulus $\left(1 \times 10^{4}\right.$ cells ml $\left.{ }^{-1}\right)$ inhibited both fecundity and egg viability (Fig. 6). Mean fecundity of females fed with the diatom for $15 \mathrm{~d}\left(1.8 \pm 2.7\right.$ eggs female $\mathrm{e}^{-1} \mathrm{~d}^{-1}$, $\mathrm{n}=30$ ) did not differ significantly from the initial in situ fecundity $\left(1.0 \pm 1.3\right.$ eggs female $\left.{ }^{-1} \mathrm{~d}^{-1}, \mathrm{n}=8\right)$ (MannWhitney $U$-test, $\mathrm{p}>0.05)$. Fecundity increased significantly $\left(12.5 \pm 11.5\right.$ eggs female $\left.\mathrm{e}^{-1} \mathrm{~d}^{-1}, \mathrm{n}=74\right)$ when the 


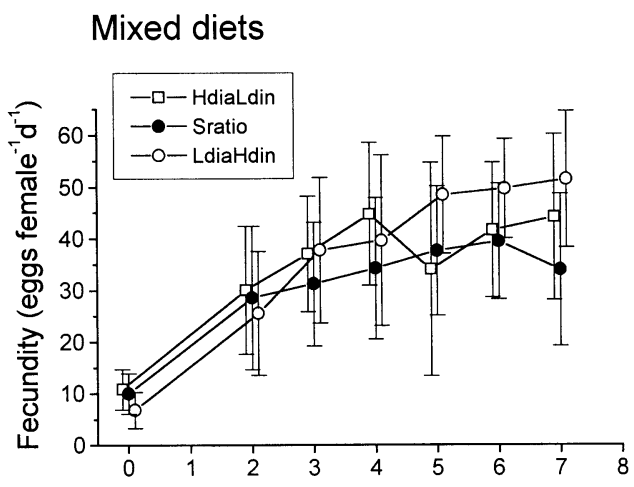

Single diets
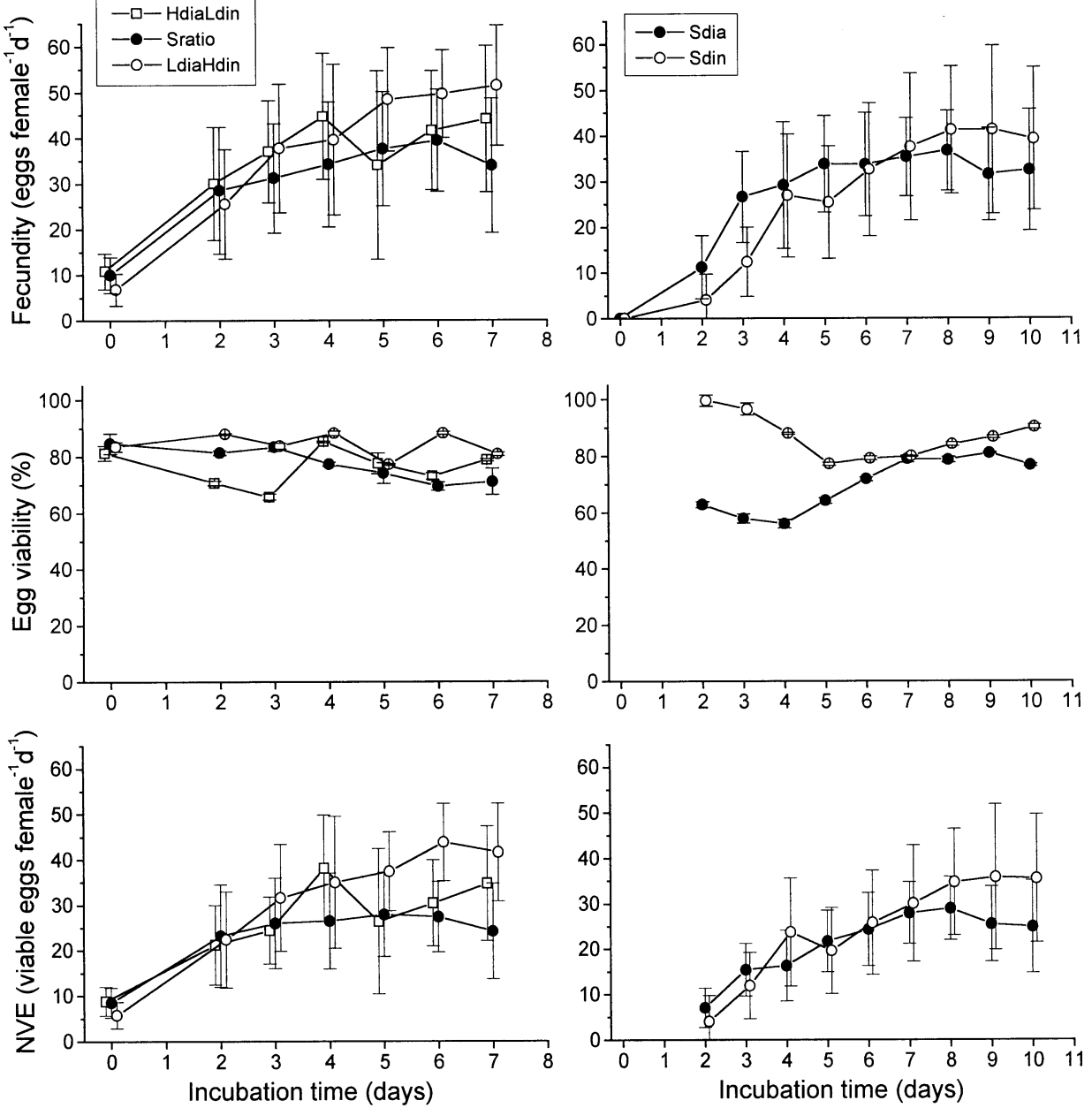

Fig. 2. Calanus helgolandicus. Fecundity, egg viability and number of viable eggs (NVE) of females fed on mixed (6 d) and single $(9 \mathrm{~d})$ diets of Coscinodiscus curvatulus and Gymnodinium sanguineum. Concentrations and proportions of diatom and dinoflagellate as in Fig. 1. Day $0=$ in situ rates prior to start of experiments. Data are means $\pm \mathrm{SD}$ ( $\mathrm{n}=6$, number of vials for fecundity and $\mathrm{NVE}_{;} \mathrm{n}=6$, number of chambers for egg viability)

\section{Mixed diets}

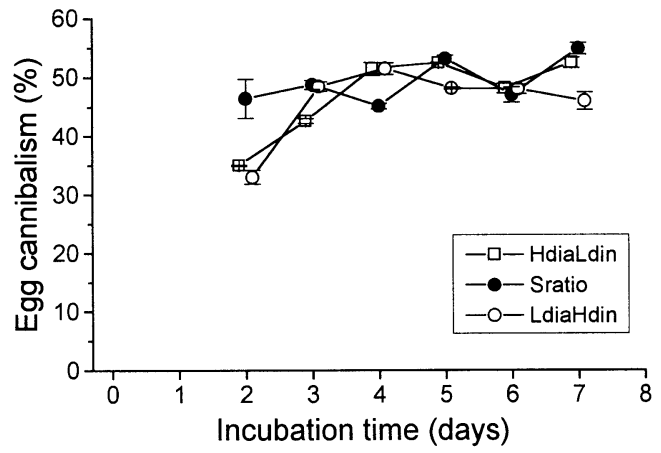

\section{Single diets}

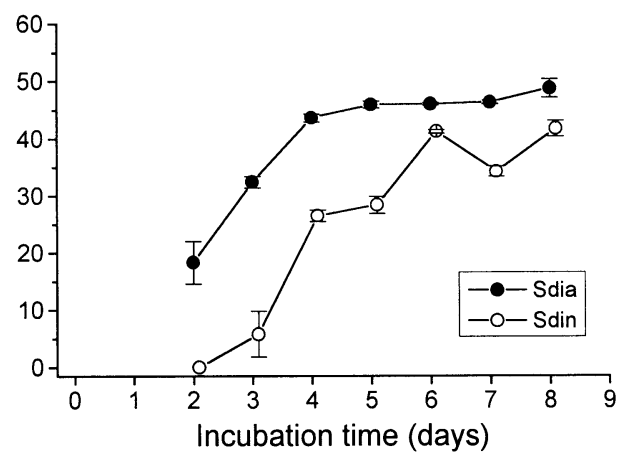

Fig. 3. Calanus helgolandicus. Egg cannibalism of females fed mixed (6 d) and single ( $7 \mathrm{~d})$ diets of Coscinodiscus curvatulus and Gymnodinium sanguineum in feeding experiments using rotating wheel. Concentrations and proportions of diatom and dinoflaellate in diets as in Fig. 1, incubation time as in Fig. 2. Data are means $\pm \operatorname{SD}(n=6$, number of jars) 

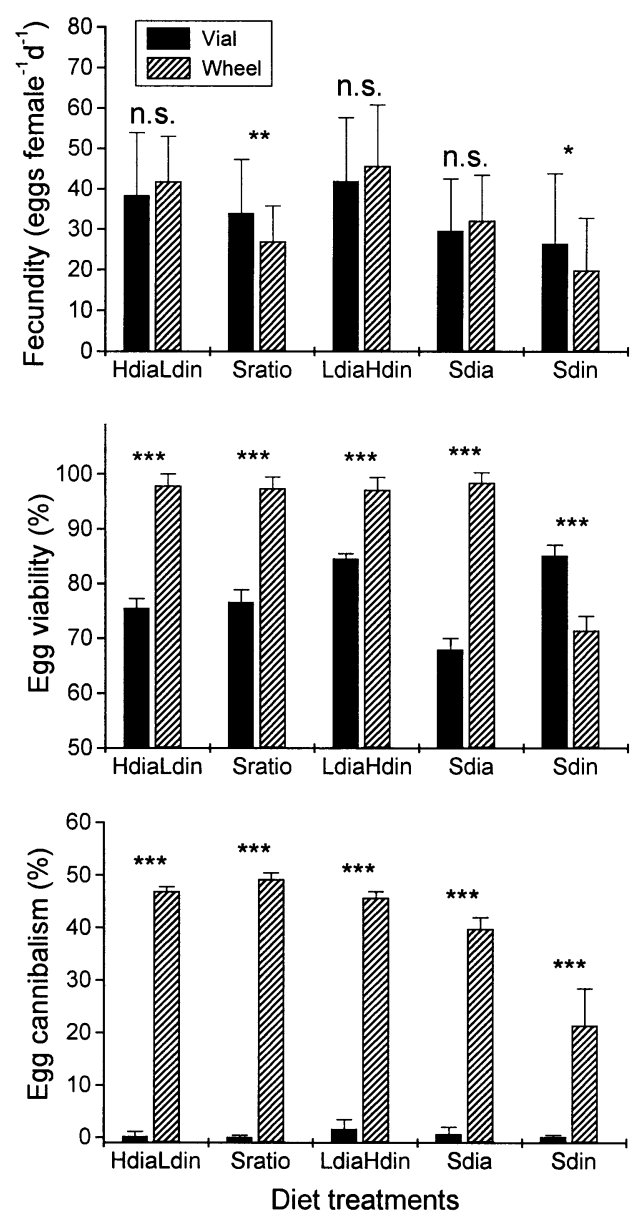

Fig. 4. Calanus helgolandicus. Comparison between mean fecundity, egg viability and egg cannibalism of females fed mixed $(6 \mathrm{~d})$ and single $(7 \mathrm{~d})$ diets using 2 incubation methods: vial and rotating wheel. Concentrations and proportions of diatom and dinoflagellate in diets as in Fig. 1. Data are means $\pm \mathrm{SD}(\mathrm{n}=6$, number of vials for fecundity; $\mathrm{n}=6$, number of jars for egg cannibalism; $n=30$, number of chambers for egg viability). Significant differences between the 2 methods were calculated by Mann-Whitney $U$-test for fecundity and Student's $t$-test for egg viability and egg cannibalism (ns = $\left.\mathrm{p}>0.05,{ }^{*} \mathrm{p}<0.05,{ }^{* *} \mathrm{p}<0.01,{ }^{* * *} \mathrm{p}<0.0001\right)$

diatom was replaced by the dinoflagellate Gymnodinium sanguineum at a lower cell concentration $(4 \times$ $10^{2}$ cells $\mathrm{ml}^{-1}$ ) for $10 \mathrm{~d}$ (Mann-Whitney $U$-test, $\mathrm{p}<$ $0.0001)$, while egg viability quickly decreased to nearzero for the first $15 \mathrm{~d}(9.5 \pm 6.5 \%: \mathrm{n}=19)$; this was significantly lower than the initial in situ egg viability $(45.5 \pm 1.0 \%, \mathrm{n}=9)$ (Student's $t$-test, $\mathrm{p}<0.0001)$, indicating strong inhibition of hatching success by the diatom. Egg viability, however, increased significantly $(95.2 \pm 3.3 \%, \mathrm{n}=56)$ when the diatom was replaced by the dinoflagellate (Student's $t$-test, $\mathrm{p}<0.0001$ ). With the diatom diet, faecal pellet production decreased and fluctuated slightly around a mean of $13.2 \pm 15.1$ pellets
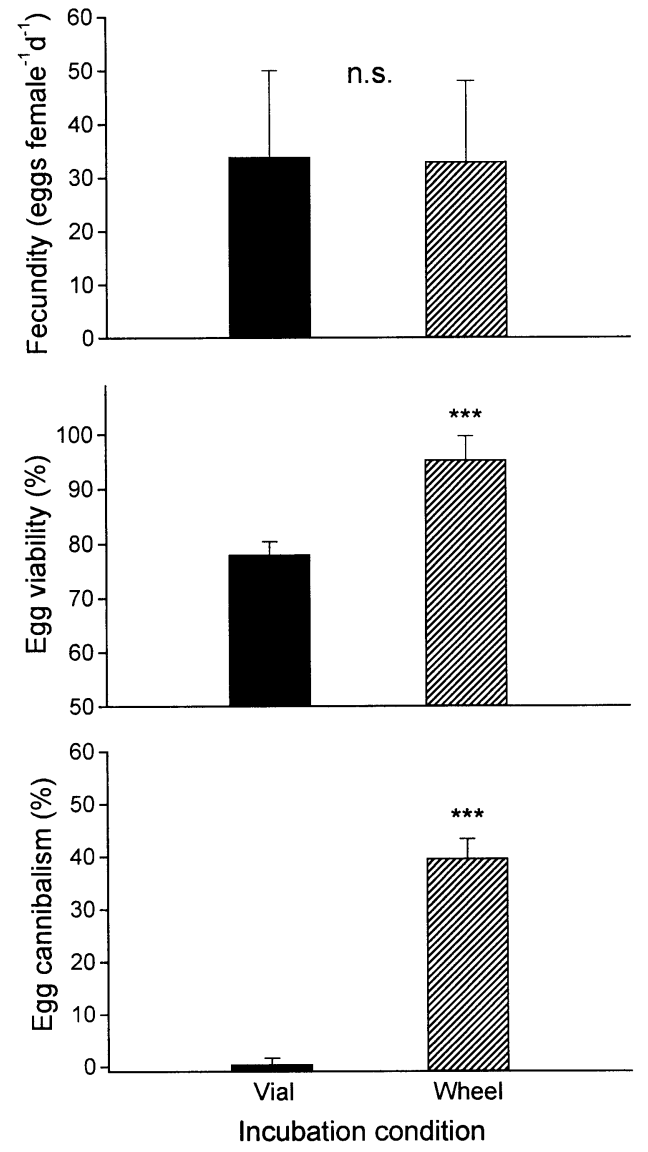

Fig. 5. Calanus helgolandicus. Effect of incubation conditions on mean fecundity, egg viability and egg cannibalism calculated from pooled data for mixed (HdiaLdin, Sratio and LdiaHdin, 6 d) and single (Sdia and Sdin, 7 d) diets using 2 different incubation methods: vial and rotating wheel. (ns = $\left.\mathrm{p}>0.05,{ }^{* * *} \mathrm{p}<0.0001\right)$

female $^{-1} d^{-1}(n=309)$ for the $15 d$ experiment. Pellet production increased significantly with the dinoflagellate diet, with a mean of $27.1 \pm 20.7$ pellets female ${ }^{-1} \mathrm{~d}^{-1}$ ( $\mathrm{n}=71$ ) for the $10 \mathrm{~d}$ experiment (Mann-Whitney $U$-test, $\mathrm{p}<0.0001$ ). Egg cannibalism was almost zero over the $25 \mathrm{~d}$ period.

\section{DISCUSSION}

Our feeding experiments showed that Calanus helgolandicus females were non-selective feeders, ingesting either diatoms or dinoflagellates at the same rates in proportion to their concentrations in the diets (Fig. 1, Table 3). Previous examinations of faecal pellets had already revealed that neither $C$. helgolandicus nor $C$. finmarchicus feed selectively on diatoms or dinoflagellates (Urban et al. 1992, Laabir et al. 1995b). Lee et al. (1999) also found that Pseudocalanus newmani con- 

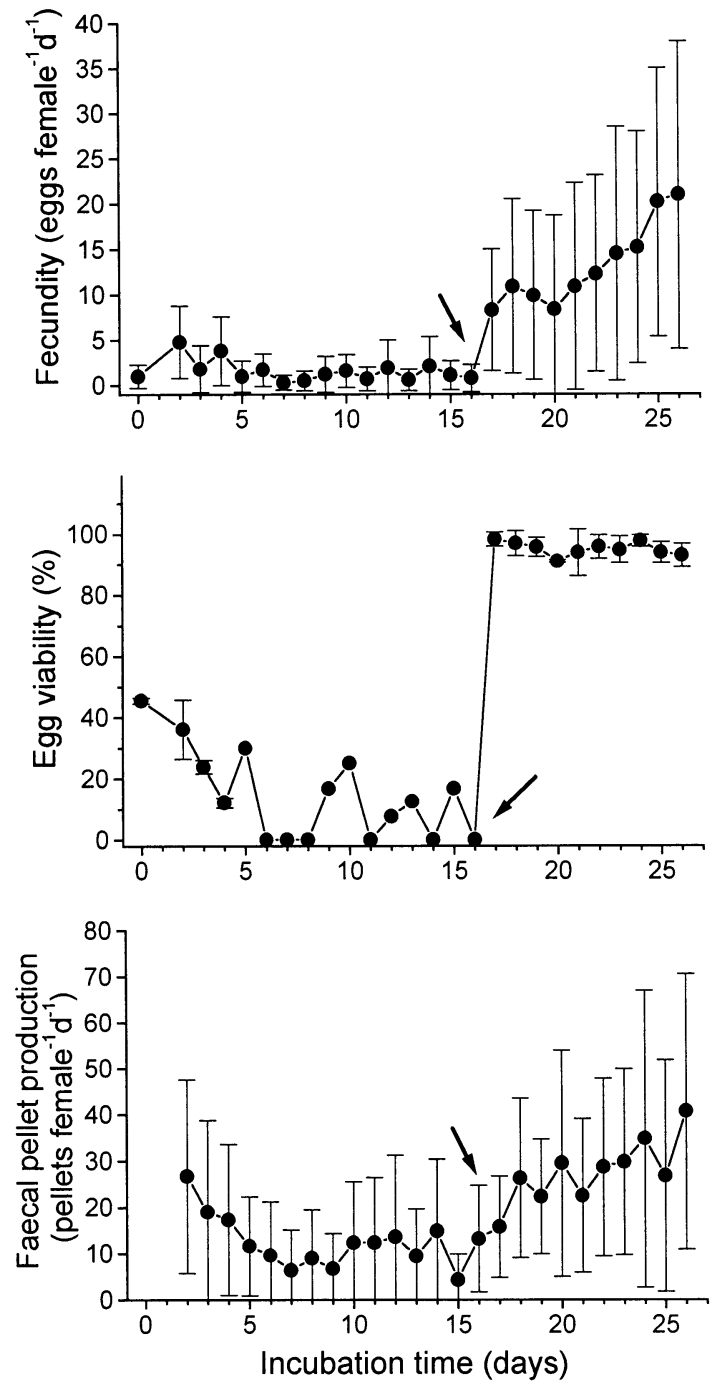

Fig. 6. Calanus helgolandicus. Responses of females to dietary shift. Initial food conditions were maintained for $15 \mathrm{~d}$ (single diet of diatom Coscinodiscus curvatulus: $1 \times 10^{4}$ cells $\mathrm{ml}^{-1}$ ), and then (arrows) replaced by dinoflagellate Gymnodinium sanguineum $\left(4 \times 10^{2}\right.$ cells $\left.\mathrm{ml}^{-1}\right)$. Day $0=$ initial in situ rates. Data are means $\pm \mathrm{SD}(\mathrm{n}=6$, number of vials for fecundity; $\mathrm{n}=6$, number of vials for faecal pellet production; $\mathrm{n}=30$, number of chambers for egg viability)

sumes Chaetoceros gracilis and Pavlova sp. non-selectively in mixed-diet treatments. However, MeyerHarms et al. (1999) reported that female C. finmarchicus positively selected dinoflagellates before and after a spring bloom, despite their minor importance in the natural phytoplankton population, whereas positive selection for diatoms occurred during the bloom. Our results (Figs. 3, $4 \&$ 5, Table 5) also showed that $C$. helgolandicus cannibalise their own eggs at high phytoplankton concentrations. Species of Calanus are capable of carnivorous feeding (Landry 1981). Turner
(1984) concluded that Calanus are mainly omnivorous, being primarily and broadly herbivorous, and shift to carnivory chiefly during periods of phytoplankton scarcity. Omnivory and egg cannibalism provide high nutritional diversity to $C$. helgolandicus, and this appears to lessen the deleterious effect of singlediatom diets on fecundity and egg viability in this genus (Figs. 2, 4 \& 6, Table 5).

At what density can diatoms inhibit reproduction in copepods? In laboratory experiments testing several copepod species, diatoms within the $10^{3}$ to $10^{5}$ cells $\mathrm{ml}^{-1}$ range and even lower $\left(10^{2}\right.$ cells $\left.\mathrm{ml}^{-1}\right)$ affected fecundity and/or egg viability. Thalassiosira nordenskioldii was reported to reduce egg viability in Calanus finmarchicus by Ban et al. (1997), while Chaudron et al. (1996) found egg viability to be dependent on diatom in the laboratory experiments, and showed that the higher the density of diatoms and the longer they were ingested, the lower the copepod hatching success, and the lower the diatom concentration, the longer the time-lag inducing blockage of egg development. Under field conditions, Miralto et al. (1999) reported egg viability of Acartia clausi in the North Adriatic Sea to be drastically reduced during a diatom bloom $\left(10^{2}\right.$ to $10^{3}$ cells $\left.\mathrm{ml}^{-1}\right)$ dominated by Skeletonema costatum and Pseudonitzschia delicatissima. In our fecundity experiments using mixed and single diets at a concentration of $10^{3}$ diatoms $\mathrm{ml}^{-1}$ (Sdia and HdiaLdin; Table 5, Fig. 2), there was no strong inhibition of egg viability and fecundity, despite egg cannibalism. Inhibition rates were of the same order of magnitude as those recorded in the field by Laabir et al. (1995b), and were lower than that recorded offshore of Plymouth, England by Pond et al. (1996). Singlediatom diets of $10^{4}$ cells ml ${ }^{-1}$ (Hdia; Table 5, Fig. 6) strongly inhibited both egg viability and fecundity, supporting the results of Chaudron et al. (1996).

Our fecundity experiments showed that with $10^{4}$ diatoms $\mathrm{ml}^{-1}$ addition of the dinoflagellate Gymnodinium sanguineum and high egg cannibalism decreased the inhibition of egg viability and fecundity (HdiaLdin; Table 5), implying that the dinoflagellate and egg cannibalism moderated the deleterious effect of diatoms. Our experiments also showed that at diatom concentrations of $<10^{4}$ cells $\mathrm{ml}^{-1}$, egg viability increased by $10.1 \%$ after the addition of a non-diatom dietary item such as G. sanguineum (Sdia and HdiaLdin; Table 5), suggesting that a dinoflagellate diet can improve egg viability. Our results further demonstrated that egg viability significantly increased at time of high egg cannibalism, regardless of dietary treatments, whereas fecundity was not affected (Fig. 5). These new results have revealed an unexpected effect of egg cannibalism on hatching success in copepods. In future, egg cannibalism should be taken into account 
Table 5. Calanus helgolandicus. Summary of results of the 6 diet treatments, comparing mean fecundity and egg viability in relation to concentrations of diatom Coscinodiscus curvatulus and dinoflagellate Gymnodinium sanguineum in diets, and to egg cannibalism. Results are shown for 2 incubation methods: vial and wheel

\begin{tabular}{|c|c|c|c|c|c|c|}
\hline Diet treatment & Hdia & HdiaLdin & Sdia & Sdia & HdiaLdin & HdiaLdin \\
\hline $\begin{array}{l}\text { Cell density in diet (cells m } \mathbf{~ m}^{-1} \\
\text { Coscinodiscus curvatulus } \\
\text { Gymnodinium sanguineum }\end{array}$ & $\begin{array}{c}1 \times 10^{4} \\
0\end{array}$ & $\begin{array}{l}1 \times 10^{4} \\
1 \times 10^{2}\end{array}$ & $\begin{array}{c}1.6 \times 10^{3} \\
0\end{array}$ & $\begin{array}{c}1.6 \times 10^{3} \\
0\end{array}$ & $\begin{array}{l}1.3 \times 10^{3} \\
2.1 \times 10^{2}\end{array}$ & $\begin{array}{l}1.3 \times 10^{3} \\
2.1 \times 10^{2}\end{array}$ \\
\hline $\begin{array}{l}\text { Egg cannibalism (\%) } \\
\text { Mean } \pm \mathrm{SD} \\
(\mathrm{n}) \\
\text { Significance } \\
\text { (Student's } t \text {-test) }\end{array}$ & $\begin{array}{c}\sim 0 \\
\begin{array}{c}(162) \\
\mathrm{p}\end{array}<0.0001\end{array}$ & $\begin{array}{c}68.0 \pm 7.1 \\
(6)\end{array}$ & $\begin{array}{c}0.7 \pm 1.3 \\
\quad(188) \\
p<0.0001\end{array}$ & $\begin{array}{c}39.8 \pm 2.2 \\
(42)\end{array}$ & $\begin{array}{c}0.2 \pm 0.9 \\
\quad(167) \\
p<0.0001\end{array}$ & $\begin{array}{c}46.9 \pm 0.9 \\
(36)\end{array}$ \\
\hline $\begin{array}{l}\text { Incubation } \\
\text { Condition } \\
\text { Duration (d) }\end{array}$ & $\begin{array}{c}\text { Vial } \\
6\end{array}$ & $\begin{array}{l}\text { Wheel } \\
\quad 6\end{array}$ & $\begin{array}{c}\text { Vial } \\
7\end{array}$ & $\begin{array}{c}\text { Wheel } \\
7\end{array}$ & $\begin{array}{c}\text { Vial } \\
6\end{array}$ & $\begin{array}{l}\text { Wheel } \\
6\end{array}$ \\
\hline $\begin{array}{l}\text { Fecundity (eggs female } \mathbf{~}^{\mathbf{1}} \mathbf{d}^{\mathbf{- 1}} \text { ) } \\
\text { Mean } \pm \text { SD } \\
\text { (n) } \\
\text { Significance } \\
\text { (Mann-Whitney } U \text {-test) }\end{array}$ & $\begin{array}{c}2.3 \pm 3.2 \\
\quad(163) \\
p<0.0001\end{array}$ & $\begin{array}{c}19.1 \pm 13.1 \\
(30)\end{array}$ & $\begin{array}{l}29.6 \pm 12.9 \\
\quad(188) \\
p>0.05 \mathrm{~ns}\end{array}$ & $\begin{array}{c}32.1 \pm 11.3 \\
(42)\end{array}$ & $\begin{array}{c}38.4 \pm 15.5 \\
167 \\
p>0.05 \text { n.s. }\end{array}$ & $\begin{array}{c}41.8 \pm 11.2 \\
36\end{array}$ \\
\hline $\begin{array}{l}\text { Egg viability (\%) } \\
\text { Mean } \pm \mathrm{SD} \\
(\mathrm{n}) \\
\text { Significance } \\
\text { (Student's } t \text {-test) }\end{array}$ & $\begin{array}{l}14.8 \pm 7.1 \\
\quad(10) \\
p<0.0001\end{array}$ & $\begin{array}{c}86.8 \pm 7.8 \\
(50)\end{array}$ & $\begin{array}{l}67.9 \pm 2.1 \\
(156) \\
p<0.0001\end{array}$ & $\begin{array}{l}98.4 \pm 1.9 \\
\quad(105)\end{array}$ & $\begin{array}{l}75.5 \pm 1.7 \\
142 \\
p<0.0001\end{array}$ & $\begin{array}{c}97.9 \pm 2.1 \\
116\end{array}$ \\
\hline $\begin{array}{l}\text { Diatom inhibition } \\
\text { Fecundity } \\
\text { Egg viability }\end{array}$ & $\begin{array}{l}\text { Strong } \\
\text { Strong }\end{array}$ & $\begin{array}{l}\text { Weak } \\
\text { No }\end{array}$ & $\begin{array}{c}\text { No } \\
\text { Weak }\end{array}$ & $\begin{array}{l}\text { No } \\
\text { No }\end{array}$ & $\begin{array}{c}\text { No } \\
\text { Weak }\end{array}$ & $\begin{array}{l}\text { No } \\
\text { No }\end{array}$ \\
\hline
\end{tabular}

in experimental studies concerning the egg viability of copepods. In contrast to the egg cannibalism recorded in laboratory studies, egg cannibalism by copepods is not well known in the field (Kiørboe et al. 1988, Liang et al. 1994, Peterson \& Kimmerer 1994). It is likely that some of the eggs sink through the water column, are dispersed by water mixing and currents, or consumed by other predators (Cabal et al. 1997, Tang et al. 1998), thus escaping predation by adults of their own species. The possible coupling of egg predation, cannibalism and egg viability may have several demographic implications that have yet to be addressed.

In what way could egg cannibalism enhance egg viability in Calanus helgolandicus? First, eggs constitute a nutritional supplement, and second ingestion of non-diatom foods moderates the effect of the deleterious diatom compounds. Eggs of $C$. helgolandicus are rich in nutrients, with triacylglycerol as the main lipid class (Lee et al. 1972, Gatten et al. 1980), important amounts of the saturated fatty acid 16:0 and the polyunsaturated fatty acids 20:5(n-3) and 22:6(n-3) (Pond et al. 1996), 4.8 to $13.1 \%$ carbohydrate (\% body weight) (Guisande \& Harris 1995), and $53 \pm 5 \mathrm{ng}$ free amino acids per egg (Laabir et al. 1999). They could therefore appear to constitute a good source of food, capable of enhancing egg viability. In addition, egg cannibalism (as well as dinoflagellates) may reduce or delay the accumulation of diatom inhibitors during oogenesis, assuming that these inhibitors can be partially metabolised by digestive enzymes, as indicated by Chaudron et al. (1996).

The present results clarify our conception of the mechanism of diatoms inhibition of copepod reproduction. Egg mortality is proportional to both diatom concentration and copepod ingestion rate. There is clearly a critical threshold concentration of diatoms $\left(10^{2}\right.$ to $10^{3}$ cells $\mathrm{ml}^{-1}$ in the present study), which may be masked by ambient food diversity (Table 5). Below this threshold, egg mortality cannot be explained by the diatominhibition hypothesis of Ban et al. (1997), but is more probably related to the nutritional value of available food (Jónasdóttir \& Kiørboe 1996, Pond et al. 1996); above this threshold, egg mortality can be explained by diatom inhibition. We hypothesize that this critical threshold concentration is species-specific in both copepods and diatoms. The degree of inhibition appears to be diatom-density-dependent (Chaudron et al. 1996, present study). The reproductive response can be moderated when females consume a high variety of food, including dinoflagellates and copepod eggs. 
Acknowledgements. We thank the team of Roscoff sailors for collecting samples at sea. Four anonymous referees are gratefully acknowledged for critical advice and suggestion. This work was funded by the Roscoff Marine Station and the Biodiversity National French Programme. A post-doctoral fellowship was granted to H.-K.K. by the Korea Research Foundation.

\section{LITERATURE CITED}

Ban S, Burns C, Castel J, Chaudron Y, Christou E, Escribano R, Fonda Umani S, Gasparini S, Guerrero Ruiz F, Hoffmeyer M, Ianora A, Kang HK, Laabir M, Lacoste A, Miralto A, Ning X, Poulet S, Rodriguez V, Runge J, Shi J, Starr M, Uye S, Wang Y (1997) The paradox of diatomcopepod interactions. Mar Ecol Prog Ser 157:287-293

Cabal J, Harris LR, Head EJH (1997) Egg production rates of Calanus finmarchicus in the Northwest Atlantic (Labrador Sea). Can J Fish Aquat Sci 54:1270-1279

Chaudron Y, Poulet SA, Laabir M, Ianora A, Miralto A (1996) Is hatching success of copepod eggs diatom densitydependent? Mar Ecol Prog Ser 144:185-193

Conover RJ (1960) The feeding behavior and respiration of some marine planktonic Crustacea. Biol Bull 119:399-415

Frost BW (1972) Effects of size and concentration of food particles on the feeding behavior of the marine planktonic copepod Calanus pacificus. Limnol Oceanogr 17:805-815

Gatten RR, Sargent JR, Forsberg TEV, O'Hara SCM, Corner EDS (1980) On the nutrition and metabolism of zooplankton. XIV. Utilization of lipid by Calanus helgolandicus during maturation and reproduction. J Mar Biol Assoc UK 60: 391-399

Guisande C, Harris RP (1995) Effect of total organic content of eggs on hatching success and naupliar survival in the copepod Calanus helgolandicus. Limnol Oceanogr 40: $476-482$

Harrison KE (1990) The role of nutrition in maturation, reproduction and embryonic development of decapod crustaceans: a review. J Shellfish Res 9:1-28

Ianora A, Miralto A, Buttino I, Romano G, Poulet SA (1999a) First evidence of some dinoflagellates reducing male copepod fertilization capacity. Limnol Oceanogr 44: 147-153

Ianora A, Miralto A, Poulet SA (1999b) Are diatoms good or toxic for copepods? Reply to comment by Jónasdóttir et al. Mar Ecol Prog Ser 177:305-308

Jónasdóttir SH (1994) Effects of food quality on the reproductive success of Acartia tonsa and Acartia hudsonica: laboratory observations. Mar Biol 121:67-81

Jónasdóttir SH, Kiørboe T (1996) Copepod recruitment and food composition: do diatoms affect hatching success? Mar Biol 125:743-750

Keller MD, Selvin RC, Claus W, Guillard RRL (1987) Media for the culture of oceanic ultraphytoplankton. J Phycol 23:633-638

Kiørboe T, Møhlenberg F, Tiselius P (1988) Propagation of planktonic copepods: production and mortality of eggs. Hydrobiologia 167/168:219-225

Laabir M, Poulet SA, Ianora A (1995a) Measuring production and viability of eggs in Calanus helgolandicus. J Plankton Res 17:1125-1142

Laabir M, Poulet SA, Ianora A, Miralto A, Cueff A (1995b) Reproductive response of Calanus helgolandicus. II. In situ inhibition of embryonic development. Mar Ecol Prog Ser 129:97-105

Laabir M, Poulet SA, Cueff A, Ianora A (1999) Effect of diet on levels of amino acids during embryonic and naupliar development of the copepod Calanus helgolandicus. Mar Biol 134:89-98

Landry MR (1981) Switching between herbivory and carnivory by the planktonic marine copepod Calanus pacificus. Mar Biol 65:77-82

Lee HW, Ban S, Ando Y, Ota T, Ikeda T (1999) Deleterious effect of diatom diets on egg production and hatching success in the marine copepod Pseudocalanus newmani. Plankton Biol Ecol 46:104-112

Lee RF, Nevenzel JC, Paffenhöfer GA (1972) The presence of wax esters in marine planktonic copepods. Naturwissenschaften 59:406-411

Liang D, Uye S, Onbé T (1994) Production and loss of eggs in the calanoid copepod Centropages abdominalis Sato in Fukuyama Harbor, the Inland Sea of Japan. Bull Plankton Soc Jpn 41:131-142

Mauchline J (1998) The biology of calanoid copepods. Adv Mar Biol 33:1-710

Meyer-Harms B, Irigoien X, Head R, Harris R (1999) Selective feeding on natural phytoplankton by Calanus finmarchicus before, during, and after the 1997 spring bloom in the Norwegian Sea. Limnol Oceanogr 44:154-165

Miralto A, Barone G, Romano G, Poulet SA, Ianora A, Russo GL, Buttino I, Mazzarella G, Laabir M, Cabrini M, Giacobbe MG (1999) The insidious effect of diatoms on copepod reproduction. Nature 402:173-176

Peterson WT, Kimmerer WJ (1994) Processes controlling recruitment of the marine calanoid Temora longicornis in Long Island Sound: egg production, egg mortality and cohort survival rates. Limnol Oceanogr 39:1594-1605

Pond D, Harris R, Head R, Harbour D (1996) Environmental and nutritional factors determining seasonal variability in the fecundity and egg viability of Calanus helgolandicus in coastal waters off Plymouth, UK. Mar Ecol Prog Ser 143:45-63

Poulet SA, Ianora A, Miralto A, Meijer L (1994) Do diatoms arrest embryonic development in copepods? Mar Ecol Prog Ser 111:79-86

Poulet SA, Laabir M, Ianora A, Miralto A (1995) Reproductive response of Calanus helgolandicus. I. Abnormal embryonic and naupliar development. Mar Ecol Prog Ser 129: 85-95

Støttrup JG, Jensen J (1990) Influence of algal diet on feeding and egg-production of the calanoid copepod Acartia tonsa Dana. J Exp Mar Biol Ecol 141:87-105

Strathmann RR (1967) Estimating the organic carbon content of phytoplankton from cell volume or plasma volume. Limnol Oceanogr 12:411-418

Tang KW, Dam HG, Feinberg LR (1998) The relative importance of egg production rate, hatching success, hatching duration and egg sinking in population recruitment of two species of marine copepods. J Plankton Res 20:1971-1987

Turner JT (1984) The feeding ecology of some zooplankters that are important prey items of larval fish. NOAA Natn Mar Fish Tech Serv Rep US Dep Commerce 7:1-28

Urban JL, McKenzie CH, Deibel D (1992) Seasonal differences in the content of Oikopleura vanhoeffeni and Calanus finmarchicus faecal pellets: illustrations of zooplankton food web shifts in coastal Newfoundland waters. Mar Ecol Prog Ser 84:255-264

Uye S (1996) Induction of reproductive failure in the planktonic copepod Calanus pacificus by diatoms. Mar Ecol Prog Ser 133:89-97

Zar JH (1984) Biostatistical analysis, 2nd edn. Prentice-Hall, Englewood Cliffs, NJ

Submitted: August 30, 1999; Accepted: December 16, 1999

Proofs received from author(s): July 7, 2000 